\title{
The Effect of Different Starter Dosage to Organoleptic Value of Kefir Cow Milk Products
}

\author{
Tivani Ardini*, Nurmiati, Periadnadi \\ Faculty of Mathematics and Natural Sciences, Andalas University \\ *Email: tivani12411@gmail.com
}

\begin{abstract}
The study of "The Effect of Different Starter Dosage to Organoleptic Value of Kefir Cow Milk Products" was carried out from May to July 2016 at the Microbiology Research Laboratory, Department of Biology, Faculty of Mathematics and Natural Sciences, Andalas University, Padang. The purpose of this study was to determine the organoleptic value (aroma, taste and organoleptic) of cow's milk kefir products from three different starter doses, and the results were with Wilcoxon Level Test. The results showed that organoleptic assessment of the aroma of cow milk kefir products with a treatment dose of $15 \%$ starter (3.00) was the most preferred dose for the panelist, while kefir with a treatment dose of 5\% (2.27) is a dose that is less preferred by panelists. The taste assessment of the organoleptic of cow's milk kefir products, the starter dose of $10 \%$ (2.87) was the most preferred by the panelists, but the dose of $15 \%$ (2.33) was the least. Similar to the taste, the consistency of cow milk kefir with the dose of 10\% (3.07) was most preferred, while the dose of 15\% (2.33) was least preferred by the panelists.
\end{abstract}

Keywords: dosage, cow milk kefir, organoleptic assessment

\section{INTRODUCTION}

Kefir is one of the fermented milk products which contain of bacteria and yeast that work symbiotically and produce organic acid compounds, $\mathrm{CO} 2$ and alcohol. Kefir contains $0.65-1.33 \mathrm{~g} / 1 \mathrm{CO} 2,3.16-3.18 \%$ protein, 3.07$3.17 \%$ fat, 1.8 to $3.8 \%$ lactose, $0.5-1.5 \%$ ethanol and $0.7-$ $1.0 \%$ lactic acid [1].

The kefir was produced from fermented milk by lactic acid producing bacteria, acetic acid producing bacteria and yeast. The taste of kefir is dominated by sour taste caused by the activity of acid-producing bacteria [2], which originally from the Caucasus mountain region between the Black Sea and the Caspian Sea, Southwest Russia. Kefir has also known as kepi, kippe, kapov, kephir and kiaphir, and has been widely consumed in several Asian and Scandinavian countries [3]. In Indonesia this type of fermented milk has not been publically known.

Kefir was produced from milk which is fermented by lactic acid bacteria such as Lactobacillus lactis, Lactobacillus delbrueckii subsp. bulgaricus and yeast that produces acid and alcohol. At the end of the ripening process, it should be covered to form carbonates [4]. The bacteria contained in kefir are homo-fermentative lactic acid bacteria which produce $90 \%$ lactic acid [5], and dominated by Lactobacillus groups [6]. Lactobacillus bulgaricus and Streptococcus thermophilus are bacteria that can be found in warm to hot, tropical and subtropical regions [7].

Kefir fermentation can be lasts for 18-24 hours at the temperature of $22^{\circ} \mathrm{C}$ [8]. Two groups of microorganisms, lactic acid bacteria and Candida yeast, were work in symbiosis in kefir fermentation. Lactic acid was produced by lactic acid bacteria from glucose breakdown which stimulates yeast growth. While yeast is important in kefir fermentation process, because it produces ethanol compounds and flavor-forming components, so produce a distinctive taste [3]. Organoleptic properties are food compounds which were assessed using the five senses of subjective judgments [9]. Organoleptic tests are commonly used for commodity quality checks, process control during processing and as a method of measurement and measurement of quality properties in research. The value was assessed by the sense of smell, taste and stimulation of the mouth [10]. So far, there is no study has been done on organoleptic values (aroma, taste and organoleptic) of cow's milk kefir products that assessed on three different starter doses $(5 \%, 10 \%$ and $15 \%)$. Therefore this study was conducted to investigate the effect of three different doses of starters to the organoleptic of kefir produced.

\section{RESEARCH METHOD}

The research was conducted from May to July 2016 at the Microbiology Research Laboratory, Department of Biology, Faculty of Mathematics and Natural Sciences, Andalas University, Padang. The data obtained was analysed in Wilcoxon tests. Before organoleptic assessment, cow milk kefir was made using a $10 \%$ starter per volume of ultra-high temperature( UHT) cow milk that was fermented for 36 hours in the following sequences: 24 hours was fermented at $25^{\circ} \mathrm{C}$, then 12 hours was fermented at $5{ }^{\circ} \mathrm{C}$ [11]. For this study, kefir was made of three doses $(5 \%, 10 \%$, and $15 \%)$ per volume of the UHT cow milk. These tree different kefir contents were tested on 15 panelists. Control was also performed using commercial kefir product.

\section{RESULTS AND DISCUSSION}

Results

Algasida EhEp Activity Level

The level of algae activity can be known by calculating the percentage of treatment algae density compared to controls. Evaluation is done on the last day of observation. Calculation of the percentage of bacterial 
consortium algaside activity using the equation in [19]. Episymbiont bacteria consortium showed low algaside activity in all target plankton, except Nitzschia sp. and Porphyridium sp (Table 1).

\section{Plankton Morphology}

Plankton growth was tested to be low, except for Nitzschia sp. During the five days of observation of plankton microstructure conditions, there were various symptoms of cell damage that could be recognized from cell deformation and damage to cell components. The cytoplasm is damaged with shrinkage symptoms $>50 \%$ of its original size (Figure 1)Plankton density

Dinoflagellate density both control and treatment were evaluated daily for five days. Porphyridium sp. Plankton cell density. and the BG treated with EhEp showed a thin increase in density compared to the control (Figure 2). This also occurs with the growth of diatomic plankton groups, the pattern of growth follows control (Figure 3).

\section{Effects of Algasida Activity on Growth}

Student t-test results showed the algaside activity of EhEp episymbiont bacteria had almost no effect on plankton growth. This is indicated by no significant difference between the control and treatment at 5\% significance level, except in Nitzschia sp. The algaside activity shows a significant effect. This means that the episimbion bacteria consortium has no significant effect on the growth of dinoflagellates and diatoms (Tabel 2).

\section{Discussion}

Many bacterial isolates have been known to have the ability as algasides. The source of these isolates are planktonic bacteria. Some even develop along with algae growth explosions. The mechanism is a natural counterweight for the plankton group. Some bacteria that are known to be antagonistic in plankton are Flavobacterium sp. 5N-3 which can inhibit the growth of Gymnodinium sp. Bacillus sp. SY-1 isolated from Masan waters in South Korea was able to suppress the growth of Cochlodinium polykrikoides [20]. Bacterial isolates obtained from Japan's Kagosima Bay Saprospira sp. SS985 is even able to reduce the growth of the diatom group Chaetoceros ceratosporum [21].

Researcher [22] succeeded in isolating $P$. haloplanktis AFMB-08041 from the surface water in Masan Bay, Korea. These bacteria are able to inhibit the growth of Prorocentrum minimum up to $90 \%$ within 5 days. Observations show that plankton is directly attacked by this bacteria. The algalytic compound produced is active beta-glucosidase. Other capabilities of these bacteria can suppress the growth of various species of HABs including Alexandrium tamarense, Akashiwo sanguinea, Cochlodinium polykrikoides, Gymnodinium catenatum, and Heterosigma akashiwo. These bacteria tend to attack plankton with morphology similar to $P$. minimum such as $P$. dentatum. Therefore, the bacteria is prepared to control $\mathrm{HABs}$ in the natural environment.

This study uses bacterial isolates from EhEp. In the algaside activity test against Porphyridium sp. and BG (dinoflagelate) found that episymbiont bacteria consortium was less able to inhibit algal growth. The EhEp bacterial consortium showed $<40 \%$, with a five-day inoculation time. The algaside activity was confirmed also by the student t-test results which stated that there was no significant difference in plankton growth density between control and treatment.

EhEp bacterial consortium on Nitzschia sp. showed algaside activity tended to be significant. Its growth density showed an increase from 15,967 cells. $\mathrm{mL}^{-1}$ on the first day to 43,245 cells. $\mathrm{mL}^{-1}$. This number is smaller than the control on the fifth day which reached 54.400 cells. $\mathrm{mL}^{-}$ 1. The effect of algaside activity on Nitzschia sp. can be observed in cell damage, characterized by cell deformation and cytoplasmic shrinkage. It is also owned by Saprospira sp. SS98-5 was able to reduce the growth of the diatom group Chaetoceros ceratosporum [21].

The Nitzschia genera consists of many species and can live in fresh, brackish and sea waters. The genera has very fast reproductive abilities and can adapt to various environmental conditions. Environmental factors that influence its development are the presence of abundant nutrients, lack of predators, high DO, high temperatures and high light intensity. Some of the species have the ability to produce neurotoxins (domoic acid). In tropical waters its can be very high abundance, if the predator is a little. High abundance can trigger the appearance of species that produce toxins. Researcher [23] succeeded in isolating Nitzschia navis-varingica from Vietnamese waters which had the ability to produce domoic acid.

The Nitzschia genera consists of many species and can live in fresh, brackish and sea waters. The genera has very fast reproductive abilities and can adapt to various environmental conditions. Environmental factors that influence its development are the presence of abundant nutrients, lack of predators, high DO, high temperatures and high light intensity. Even some members of the species have the ability to produce neurotoxins (domoic acid). In tropical waters its abundance can be very high in limited predator conditions. High abundance can trigger the appearance of species that produce toxins. Researcher [23] succeeded in isolating Nitzschia navis-varingica from Vietnamese waters which had the ability to produce domoic acid.

Observations show that plankton trapped by cytoplasmic biofilms shrink. EhEp consortium bacteria can produce secondary metabolites which can seep into plankton cells. This also occurs in diatoms, where cells undergo deformation and the cytoplasm of the cell undergoes shrinkage. Researcher [24] used biosurfactant glycolipid biosurfactant sophorolipid isolated from yeast Turolopsis gabarata as algaside for Alexandrium tamarense, Heterosigma akashiwo and Cochlodinium polykrikoides. These metabolites damage the cytoplasm and lyse cell membranes. Researcher [25] found Streptomyces sp. L74 produces secondary metabolites which can disrupt the mechanism of the microcystis aeruginosa cyanobacter antioxidant. These mechanisms include indirect inhibition by producing secondary metabolites. Researcher [26] found that bacteria capable of suppressing plankton growth have the ability to produce chitinase enzymes. The enzyme can damage the diatom cell wall, so that the diatom undergoes lysis. The destruction of the cell wall is a direct attack mechanism. 


\section{CONCLUSION}

The EhEp bacterial consortium showed less significant algaside activity against diatoms and dinoflagellates, except Nitzschia sp. This fact makes the episymbiont of $E$. acoroides not yet potentially used as a source of algasida. The ability of seagrass bacteria consortium requires further study. The aspects that can be examined are episimbion interaction patterns with other planktonic microorganisms and with the seagrass. Ecological aspects that play a role in this interaction pattern can be investigated to find out the influential environmental factors, which require further study. Further things that can be developed are episymbion interaction patterns with other planktonic microorganisms and with the seagrass.

\section{REFERENCES}

[1] Marba N, Holmer M, Gacia E, Barron C. 2006. Seagrass Beds and Coastal Geochemistry. Larkum AWD, Orth RJ, Duarte CM, editor. Seagrass: Biology, Ecology and Conservation. Netherlands: Springer. p. 135-153.

[2] Michael TS, Shin HW, Hanna R, Spafford DC. 2008. A Review of Epiphyte Development: Surface Intercations and Settlement on Seagrass. J Enviro Biol [Internet]. [diunduh 2016 April]; 29(4): 629-638. Tersedia pada: www.jeb.co.in.

[3] Leliaert F, Van-Reusel W, De-Clerck O, Coppejans E. 2001. Epiphyte of Seagrass of Zanzibar Island (Tanzania), Floristic and Ecological Aspect. Belg $J$ Bot. 131(1): 3-20.

[4] Frankovich TA, Fourqurean JW. 1997. Seagrass Epiphyte Loads Along a Nutrient Avaibility Gradient, Florida Bay, USA. Mar Ecol Prog Ser. 159: 37-50.

[5] Borowitzka MA, Lavery PS, van Keulen M. 2006. Epiphyte Seagrasses. Larkum AWD, Orth RJ, Duarte CM, editor. Seagrass: Biology, Ecology and Conservation. Netherlands: Springer. p. 441-456.

[6] Kurilenko VV, Ivanova EP, Mikhailov V. 2001. Zonal Distribution of Epiphytic Microorganism on the Eelgrass Zostera marina. Microbiol. 70(3): 372-373. DOI: 10.1023/A.1010475916224.

[7] Wu H, Chen W, Wang G, Dai S, Zhou D, Zhao H, Guo Y, Ouyang Y, Li X. 2012. Culture-dependent Diversity of Actinobacteria Assosiated with Seagrass (Thalassia hemprichii). Afric J Microbiol Res. 6(1): 87-94. DOI: 10.5897/AJMR11.981.

[8] Nugraheni SA, Khoeri MM, Kusmita L, Widyastuti Y, Radjasa OK. 2010. Characterization of Carotenoid Pigments from Bacterial Symbionts of Seagrass Thalassia hemprichii. J Coast Develop. 14(1): 51-60.

[9] Merina M, Lipton AP, Wesley SG. 2011. Isolation, Characterization and Growth Respon of Biofilm Forming Bacteria Bacillus pumilus from the Seagrass, Halodhule pinifolia off Kanyakumari Coast. Indian J Mar Sci. 40(3): 443-448.

[10] Cho JY, Kang JY, Hong YK, Baek HH, Shin HW, Kim MS. 2012. Isolation and Structural Determintation of Antifouling Diketopiperazines from Marine-derived Streptomyces praecox 291-11. Biosci
Biotechnol Biochem. 76(6): http://dx.doi.org/10.1271/bbb.110943.

[11] van der Heide T, Govers LL, de Fouw J, Olff H, van der Geest M, van Katwijk MM, Piersma T, van de Koppel J, Silliman BR, Smolders AJP, van Gils JA. 2012. A Three-Stage Symbiosis Forms the Foundation of Seagrass Ecosystems. Sci. 336: 1432-1434. DOI: 10.1126/science.1219973.

[12] Garcias-Bonet N, Arrieta JM, de Santana CN, Duarte CM, Marba N. 2012. Endophytic bacterial community of a Mediterranean marine angiosperm (Posidonia oceanica). Front in Microbiol. 3: Article 342.

[13] Laabir M, Grignon-Dubois M, Masseret E, Rezzonico B, Soteras G, Rouquette M, Rieuvilleneuve F, Cecchi P. 2013. Algacidal Effect of Zostera marina L and Zostera noltii Hornem. Extracts on the Neuro-toxic Bloom-forming Dinoflagellate Alexandrium catenella. Aqua Bot. 111: 16-25. http:/dx.doi.org/10.1016/ j.aquabot.213.07.010.

[14] Ali MS, Ravikumar S, Beula JM. 2013. Larvasidal Potential of Seagrass Extracts against Dengue Vector Aedes Aegypty (Insecta: Diptera: Culicidae) [Internet]. Int J Pharm Bio Sci [diunduh 2016 Mei]; 4(2): 62-67. Tersedia pada: www.ijpbs.net.

[15] Imai I. 2015. Interactions Between Harmful Algae and Algicidal and Growth-Inhibiting Bacteria Associated with Seaweeds and Seagrasses. Ohtsuka S, Suzaki, Horiguchi T, Suzuki N, Not F, editor. Marine Protists: Diversity and Dinamics. Tokyo. Springer. DOI: 10.1007/978-4-431-55130-1 25. p.

[16] Satheesh S, Ba-akdah MA, Al-Sofyani AA. 2016. Natural Antifouling Compound Production by Microbes Associated with Marine Macroorganism. Electr J Biotechnol. 21:26-35. doi: 10.1016/j.ejbt.2016.02.002.

[17] Marhaeni B, Radjasa OK, Khoeri MM, Sabdono A, Bengen DG, Sudoyo H. 2011. Antifouling Activity of Bacterial Symbionts of Seagrasses against Marine Biofilm-Forming Bacteria. JEP. 2, 1245-1249.

[18] Nakashima T, Miyazaki Y, Matsuyama Y, Muraoka W, Yamaguchi K, Oda T. 2006. Producing mechanism of an algicidal compound against red tide phytoplankton in a marine bacterium gammaproteobacterium. Appl Microbiol Biotechnol. 73 (3): 684-90.

[19]Lee BK, Katano T, Kitamura SI, Oh MJ, Han MS. 2008. Monitoring of Algacidal Bacterium, Alteromonas sp. Strain A.14 in its Application to Natural Cochlodinium polykrikoides Blooming Seawater Using Flouresence In Situ Hibridization. J Microbiol: 274-282.

[20] Kim D, Kim JF, Yim JH, Kwon SK, Lee CH, Lee HK. 2008. Red to Red - the Marine Bacterium Hahella chejuensis and its Product Prodigiosin for Mitigation of Harmful Algal Blooms. J Microbiol. Biotechnol. 18(10): 1621-1629.

[21] Furusawa G, Yoshikawa T, Yasuda A, Sakata T. 2003. Algicidal activity and gliding motility of Saprospira sp. SS98-5. Canadian J Microbiol. 49(2): 92-100. doi: 10.1139/w03-017.

[22] Kim JD, Kim JY, Park JK, Lee CG. 2009. Selective control of the Prorocentrum minimum harmful algal blooms by a novel algal-lytic bacterium 
Pseudoalteromonas haloplanktis AFMB-008041. Mar Biotechnol. 11(4): 463-72.

[23] Lundholm N, Moestrup O. 2000. Morphology of the Marine Diatom Nitzschia navis-varingica, sp. nov. (Bacillariophyceae), another Producer of the Neurotoxin Domoic Acid. J Phycol. 36: 1162-1174. doi/10.1046/j.1529-8817.2000.99210.x

[24] Sun XX, Choi JK, Kim EK. 2004. A preliminary study on the mechanism of harmful algal bloom mitigation by use of sophorolipid treatment. J Experiment Mar Biol Ecol. 304: 35-49 doi:10.1016/j.jembe. 2003.11.020.

[25] Luo J, Wang Y, Tang S, Liang J, Lin W, Luo L. 2013. Isolation and Identification of Algicidal Compound from Streptomyces and Algicidal Mechanism to Microcystis aeruginosa. PLoS ONE 8(10): e76444. doi:10.1371/journal.pone.0076444.

[26] Li Y, Zhu H, Lei X, Zhang H, Cai G, Chen Z, Fu L, $\mathrm{Xu} \mathrm{H}$, Zheng T. 2015. The death mechanism of the harmful algal bloom species Alexandrium tamarense induced by algicidal bacterium Deinococcus sp. Y35. Front. Microbiol. http://dx.doi.org/10.3389/fmicb. 2015.00992.

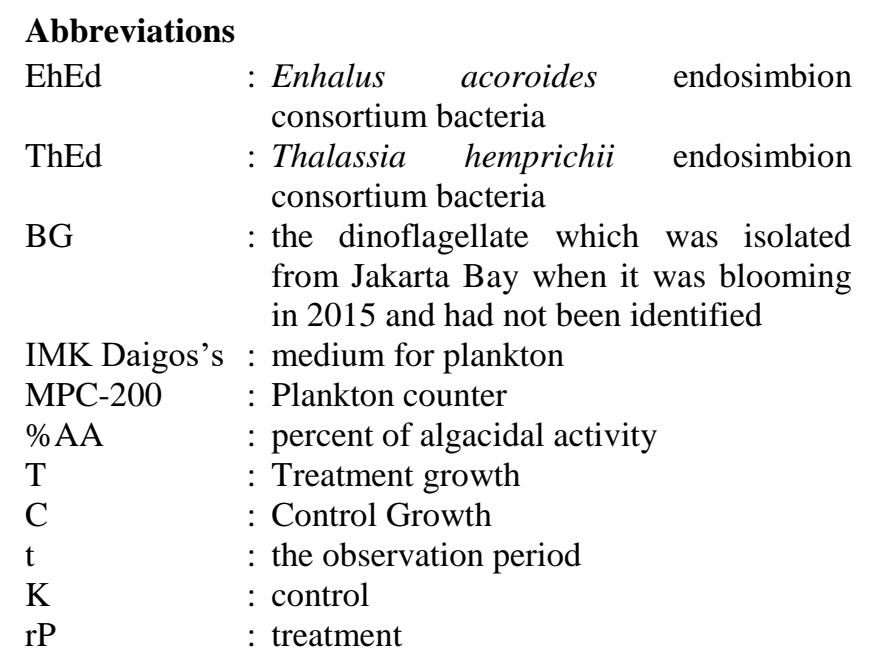

